\title{
Western Donors, Romani Organizations, and Uses of the Concept of Nation after 1989
}

\section{Douglas Neander Sambati}

dnsambati@gmail.com

Independent researcher associated with the Group of Interdisciplinary Studies on Cultural Heritage - Univille/Brazil

ORCID: https://orcid.org/0000-0003-0352-366X

Douglas Neander Sambati holds a PhD in Historical Sociology from Charles University, Czech Republic, writing his dissertation on the Historical Sociology of the Romani Nationalism: Foundations, Development and Challenges. Previously, he obtained an MA in Cultural Heritage and Society (Univille/Brazil) and a BA in History (Univille/Brazil). Among his topics of interest are nationalism, processes of identification, education, sociomuseology, anarchist theory, and minorities.

\section{Critical}

Romani Studies 


\section{Abstract}

This article discusses the relationship between Western donors and Romani and Romani-friendly organizations in Central and Eastern Europe after 1989. Based on literature review, interviews, reports, and websites, this paper upholds that the burst of Romani and Romani-friendly organizations in Central and Eastern Europe after 1989 primarily was made possible by financial support and expertise coming from Western organizations. Together with their work methodology, so-called donors took their own framework on understanding groupings and enforced the concept of nation upon Gypsy/Romani populations. Therefore, Western donors and Romani activists and intellectuals alike essentialized (claimed) Gypsy/Romani traits in order to support a nation-building rhetoric. These Romani activists and intellectuals, in turn, are a legacy of policies from planned economies, and they actually might represent Gypsy/Romani communities from a privileged perspective - no longer fully insiders but as a vanguard.

\section{Keywords}

- Roma

- Donors

- Nationalism

- Essentialization 


\section{Introduction}

As planned economies in Central and Eastern Europe crumbled after 1989, Western organizations whether national, international, or nongovernmental - recognized an unrivalled opportunity to market both their businesses and socio-economic assistance programs. This dramatically changed the landscape for Romani and Romani-friendly organizations, which rapidly increased in number (Marushiakova and Popov 2004; Vermeersch 2006).

This article understands that when Western donors - Open Society Foundations (OSF), in particular arrived in Central and Eastern Europe to address the so-called Roma issue, among others, they reinforced representations about Gypsy/Romani ${ }^{[1]}$ populations as one nation. In other words, they arrived in Central and Eastern Europe uncritically employing a nationalist perspective and structure in handling Gypsy/ Romani populations, a policy that usually was practiced and reinforced pragmatically and - to a certain extent - inattentively. As many local activists - avid to take part in new opportunities after the fall of Iron Curtain - were trained by Western organizations, they reproduced the concept of Gypsies/Roma as a one-nation conceptual structure similar to the donors and their peers.

The practices and discourses that operate "Gypsies/Roma as one nation" conceive Roma as one population (allegedly) connected by a distant past in India, who are (usually) rejected by the existent states where they live and who - not all of them, not always, and not in the same way - are suffering from and oppressed by economic, social, and political disadvantage. For instance, Hancock $(2001 ; 2005)$ reinforces a common origin for all Romani nationals, at the same time highlighting that Romani populations are treated as less than equal within majoritarian societies. McGarry (2008), Carmona (2013), and Liegeois and Gheorghe (1995) also discuss an arrival in Europe from what is today's India, lending support to the rhetoric of a common origin for Gypsy/Romani populations. Mayall (2004) points out - under a critical note - the statement from the First World Romani Congress in 1971 about the brotherhood of all Roma throughout the world. And going further in a critical approach, Law and Kovats (2018) have proposed to understand the concept of Roma as a political phenomenon. ${ }^{[2]}$ This article suggests, however, that to

\footnotetext{
1 The question of how to represent the populations that are known commonly as Gypsies is always a challenge in a text. In countries like Brazil, Portugal, Spain, the United Kingdom, and, to a certain extent, Bulgaria and Poland, the use of the local version of the word Gypsy generally is accepted (although not always, not everywhere, and not in the same way). However, in other European countries the use of this word in its local version can be (and usually is) understood by activists and/or intellectuals as offensive. This is especially the case in the Czech Republic, Germany, Hungary, and Romania. The question becomes even more complex because at the communitarian level there are groups that do not bind or accept the Roma nomenclature and continue to call themselves Gypsies, or even use Roma and Gypsy as synonyms. In this article, I decided to use the term Gypsy/Roma when referring to the general population and Roma when referring to the ethnic identity manoeuvred by the social movements from 1971 onwards. Such a decision is particularly relevant here, as the word Roma will be used less as an ethnic denomination and more as a political strategy. This is an arbitrary decision that does not comprise the entire complexity of the subject, mostly because the use of the word Gypsy (even more so when standing alone) to represent all communities seen or self-ascribed as Gypsies and/or Roma (and other denominations) glosses over social, historical, and cultural nuances of these populations.
}

2 The number of productions that discuss the nationhood of Roma, directly or indirectly, is enormous and growing fast. It is possible to name Marushiakova and Popov (2004; 2013), Niremberg (2009), Simhandl (2009), and Rövid (2011), among others. 
understand the uses of the concept of a Roma nation in the Gypsy/Romani case, it is necessary to look holistically through a political, cultural, and social lens. That is because the notion of a Roma nation cannot be summed up as the work of one international organization, or of NGOs, and so forth. The ideal of a Roma nation might have been forged by all these aforementioned actors (and their authors), but at the same time these groups also live within this ideal, without clearly realizing its characteristics, shapes, and borders. Therefore, it might be clarifying to see the Roma nation as sets of representations. As Chartier $(1990,17)$ says, the representations of the social world:

[...] although aspiring to the universality of a diagnosis founded on reason, they are always determined by the interests of the group which forged them. Hence, for each case, it is mandatory to relate the speeches delivered with the position of those who profess them.

Social perceptions are by no means neutral discourses: they produce strategies (social, academic, political) that tend to impose an authority at the expense of others, whom they disdain, to legitimize a reforming project or to justify, to the individuals themselves, their choices and behaviours. ${ }^{[3]}$

Bringing Chartier's idea to the Gypsy/Romani case, the concept of a Roma nation might be seen as lying on a nest of supposedly objective arguments, such as clear cultural and historical ties. Also, it presents itself as an idea disconnected from the actors who avow it, as if it was an impartial and solid idea. However, this sturdiness and neutrality are nothing but misinterpretation. The Roma nation is consistently created and re-created in the conflict and coexistence of those who enforce and those who dismiss such an ideal, in a unending game in which one group is trying to impose its view and its understanding over the other. That said, it is possible to affirm that the general understanding about nation - which smoothly flows around and within Romani and Romani-friendly organizations and among activists and is employed to claim Gypsies/Roma as a Roma nation - could be summarized as follows: a group with a nuclear, basic, and broad shared culture, a communal historical past expressed in a remote origin, though not necessarily attached to a specific clearly demarked land in current times.

Section one of this article discusses the match between Central and Eastern European Romani activism and Western donors' set of attitudes and strategies from a socio-historical perspective. Western donors approached the region after 1989 from a point of view that placed human groupings in terms of national majority and minorities as elaborated in their own countries. Central and Eastern European Romani activists, in turn, had experienced the historical context of the planned economy which also enforced a nationalist framework. This overlapping was a fecund environment for the application of methodological nationalism, as the concept of nation found little - if any - resistance. In other words, the outcome

3 In the original: [...] embora aspirem à universalidade de um diagnóstico fundado na razão, são sempre determinadas pelos interesses de grupo que as forjam. Daí, para cada caso, o necessário relacionamento dos discursos proferidos com a posição de quem os utiliza.

As percepções do social não são de forma alguma discursos neutros: produzem estratégias e práticas (sociais, escolares, políticas) que tendem a impor uma autoridade à custa de outros, por elas menosprezados, a legitimar um projecto reformador ou a justificar, para os próprios indivíduos, as suas escolhas e condutas (author's translation). 
of a meeting between Western donors and locally engaged people was the formation of an activist and/or intellectualized elite who enforced and applied a national framework (herein seen as representing Gypsies/Roma as one close-knit cultural and historical group) to the plural population known as Gypsies and/or Roma (and further self-identifications), even if it sometimes had to gloss over certain indications of difference (often a cultural aspect but not only). Plainly, a process of methodological nationalism was supported by sponsors, academia, and activists as there was an overall acceptance to arrange and understand groupings through the lenses of ethno-national organization.

Section two scrutinizes the example of OSF, chosen because of its long-term financial commitment to projects connected to Gypsy/Romani populations in Central and Eastern Europe that range from combating poverty and deprivation to support of a Romani Studies Program within the Central European University, itself established and sponsored by George Soros and OSF. The last section brings the concepts of nationalism and essentialism into dialogue. In order to hold up the idea of all Gypsies/Roma as one Roma nation, activists and scholars have been vocalizing some characteristics and attaching them to Gypsy/ Romani populations worldwide, and this process can lead to a process of essentialiation. Such a strategy might be valid; however, this article argues that those who have taken it upon themselves to decide the (claimed) Romani traits to be emphasized are acting as an avant-garde. All in all, vanguard groups have a tendency to be detached from the population which they claim to represent; this process of essentialization to support the political strategy of being recognized as a Roma nation does not seems to result in structural changes. The last section summarizes and connects the discussions presented in the article.

Based on literature review, interviews carried out in Central and Eastern Europe, and content of reports and websites, this article discusses how Western donors, through financial sponsorship, methodological nationalism, and strategic essentialism, helped to attach the concept of nation to Gypsy/Romani communities.

\section{Eastern European Activism As Fertile Ground for Western Donors}

A body of published articles and reports in academia and the mass media support evidence of a significant gap in the relationship between international Romani organizations - whether the International Romani Union (IRU), Roma National Council (RNC), and/or European Roma and Travellers Forum (ERTF), and so on - and local Romani or Romani-friendly organizations, and an even larger gap if considering the distance between international Romani bodies and Gypsy/Romani communities. Throughout interviews gathered during field research in Central and Eastern European countries, ${ }^{[4]}$ distance from and sometimes even unfamiliarity with the international bodies was recorded repeatedly. For instance, $B^{[5]}(2016)$, when questioned about the role of IRU in Bulgaria during the 1990s, answered "No, they were not working here." Additionally, while discussing the process of expulsion of Gypsies/Roma from France in 2011, B (2016) affirmed:

4 During 2016, interviews were carried out in Bulgaria, Czech Republic, Hungary, North Macedonia, Romania, Serbia, and Slovakia.

5 Bulgarian activist/academic of Gypsy/Romani background. 
Even after it became clear that all these attacks [were] against us, from the government [...], and the prosecutors' offices didn't find anything against Roma... that is illegal or something... they, the international Roma institutions didn't say a word... our friends from the international, so-called movement. So... what I'm saying is that these organizations are, unfortunately, far from the reality! This discussion, what they have, [it] is not grounded in the real problems in the countries.

Whether it is true or not that international Romani institutions, as called by $B$, did or did not say a word about the situation in France is not the focus of this discussion. What is relevant is the fact that an experienced activist and scholar felt comfortable expressing his thoughts in such a way. In other words, he believes that the international bodies were not actively supporting Gypsies/Roma and, mostly, that their mind-set was not grounded in the reality of Gypsy/Romani communitarian life. Similar distance was found in discourses in Bulgaria, the Czech Republic, Hungary, North Macedonia, Romania, and Serbia. At the time of the interviews (2016), the IRU was still divided, ${ }^{[6]}$ and none of these interviewees, who were everyday workers within Romani and Romani-friendly organizations, could answer anything about the IRU. The case in North Macedonia is illustrative when the interviewee $M^{[7]}$ affirmed:

For example, now, there is an IRU, International Roma Union. I mean it is an institution, organization, established from $1971 \ldots$ and, sincerely, I'm not familiar with what they're doing, except annual meetings (M 2016).

This distance between local and international practices is emphasized because the interviewee had personal contact with Mr. Zoran Dimov ${ }^{[8]}$ but claimed to have no information about what the IRU was planning or doing.

Such "empty" space between international and local organizations was occupied, after 1989, by Western donors that found fertile ground for their practices and strategies (Marushiakova and Popov 2004; Vermeesch 2006). That is because the international Romani organizations' core - at least intellectually - historically was based in Central and Eastern European countries. ${ }^{[9]}$ Thanks in part to

6 From 2013 until 2018, the IRU encountered political difficulties. During these years, at least three organizations claimed to be the real IRU: one based in North Macedonia, one based in Latvia, and one based in Romania. The latter was under leadership of Dorin Cioabă; at some point in 2016, its website went offline, and I could not gather any further information. The last news concerning this IRU was when Mr. Cioabă offered Gypsy/Romani help in the construction of the promised wall between the United States and Mexico to United States President Donald Trump (Albert and Votavová 2017). Concerning the other two IRUs, in early 2018 they apparently found common ground and started to work together.

7 Macedonian activist of Gypsy/Romani background.

8 At the time of this interview in September 2016, Mr. Dimov was president of the International Romani Union based in Skopje, North Macedonia.

9 Certainly, there were activists from Western Europe. However, the great majority of these Western actors had close connections with Eastern Europe - on personal and familial levels. 
(so-called) socialist policies ${ }^{[10]}$ throughout the region, the formation of groups of organized Gypsy/ Romani intelligentsia was encouraged. These activists and/or intellectuals have been subject to social, economic, and political strategies that, in the great majority, followed a Stalinist approach towards Gypsies/Roma, generally labelling them as proletarians and not an ethno-national group.

As Stalin began his ascent to power in the USSR in the 1920s, a Leninist approach still was directed towards the diverse ethnicities/nationalities inhabiting Soviet territory, a legacy of the Korenizatsiya ${ }^{[11]}$ policy. In short, this was a state effort to improve the lives of all ethnicities on Soviet territory, bringing them up to the same level as ethnic Russians, who were perceived as more evolved (Liber 1991; Marushiakova and Popov 2008). Such policies affected the life of Gypsy/Romani intelligentsia and activists at the time, who managed to form Gypsy co-operative farms (Gypsy kolkhozes), Gypsy co-operative artisans' workshops (Gypsy artels), develop Romani language and literature, textbooks, and a Romani theater called Romen - all with state aid (Martin 2001; Marushiakova and Popov 2008). Nevertheless, the landscape started to change after the mid-1930s, and although Gypsies/Roma were not specially targeted, the switch also touched upon their lives. From 1938 onwards a Stalinist approach about nation and nationalism spread throughout the Soviet republics (Marushiakova and Popov 2008) and their satellites - although not in the same way in each republic. Stalin $(2012,11)$ wrote:

A nation is a historically constituted, stable community of people, formed on the basis of a common language, territory, economic life, and psychological make-up manifested in a common culture.

Stalin ${ }^{[12]}$ affirms that if one of these elements is lacking in the composition of a group, they cannot be considered a nation. From Stalin's point of view and, by consequence, from Soviet institutions, Gypsies/Roma were not considered a nation and should not promote their cultural particularities; instead they should focus on their role as proletarians: all Gypsies/Roma should work and contribute to socialist life. To be able to work in and contribute to the industrialized state, Gypsies/Romani were made to attend school, and since racism was institutionally forbidden, they managed to thrive within the educational system, climbing to higher positions in Soviet society in comparison to Gypsy/Romani populations living in non-socialist countries at the time. These formally highly-educated people would

10 When working with the concept of socialism, I refer to a government-less, borderless, and non-wage system society, where the means of production and the land are co-managed and the products resulting from work are shared accordingly with personal needs. Mostly (if not all) countries which claimed to embrace a socialist experience during the twentieth century relied on a strong central government, often totalitarian, racist and violent, which centrally organized the means of production and distributed the wealth accordingly with the interest of those in charge of the bureaucratic system. For further discussion on the topic, read: Piotr Kropotkin, The Conquest of Bread (Wrocław: Johnathan-David Jackson 1892); Abdullah Öcalan Democratic Confederalism, Translated by International Initiative. London, Cologne: Transmedia Publishing Ltd. 2011); Stephen Resnickand Richard Wolff, "Between State and Private Capitalism: What Was Soviet 'Socialism'?” Rethinking Marxism 7 (1): 9-30 (1994).

11 From the early 1920s to mid-1930s, Soviet territories faced a process called Korenizatsiya (коренизация). In short, it was an attempt to enhance the non-Russian ethnic identities within the Soviet bureaucracy, theoretically raising them to the same development stage as Russian nationals (Liber 1991).

12 It might be interesting to highlight that Stalin is quoted here as an influential policymaker rather than as an intellectual. 
be those who had developed socio-political skills to nurture nationalist ideas related to Gypsy/Romani populations, engaging in the nation-building process after the fall of the Iron Curtain.

Although it would be misleading to believe that all Central and Eastern European countries under socalled socialist regimes treated their Gypsy/Romani populations the same way, it can be said that both state-controlled organizations and independent organizations were the bed rock for later Romani social, cultural, and political mobilization which exploded after 1989 (Barany 2000). About communist times, Barany $(2000,436)$ summarizes:

Aside from a few isolated examples, the Roma were not permitted to pursue mobilization activities. Thus, their political marginality in this period was rooted in exogenous political causes (e.g. obstacles posed by the state to mobilization). Nevertheless, statecontrolled Gypsy organizations and the policy to integrate the Roma into state and party hierarchies served as something of an unintended training ground for the Gypsy activists of the future. As Ivan Vesely, a Slovak Rom who became a prominent Gypsy activist in the Czech Republic, asked me: "Do you think I would be sitting here arguing about Marx and Weber if it were not for the communists? I would be in the ghetto in eastern Slovakia!” Paradoxically, through their social (especially educational) policies the socialist regimes contributed to the development of what they feared most: Romani identity formation and activism.

This ambiguity is interesting to observe: state policies striving to assimilate Gypsies/Roma within majority society were also setting the context which allowed a majority of those seen, treated, or selfascribed as Gypsy and/or Roma to achieve higher ranks of formal education and, as a result, brought to the forefront a process of relabelling ${ }^{[13]}$ Gypsy/Romani identity during post-socialism. Therefore, the overall impression of Gypsy/Romani populations before the fall of communism was, generally speaking, of a people who had their very basic living needs fulfilled, ${ }^{[14]}$ even though they faced levels of violence in a state-led process of assimilation (Hungary and Yugoslavia each had a particular different process which, however, does not change the overall landscape). Within this context, activists and/or intellectualized groups were in the right place after 1989 to receive further training and financial support from Western

13 In Portuguese, the verb requalificar (re + qualificar. The prefix "re" brings the idea that something is being made again; meanwhile the verb 'qualificar' might be translated as "to qualify," "to describe," or "to designate") is used when discussing the rethinking and rewriting of historiographic knowledge aiming to develop a different status to a given subject. In studies about cultural heritage such a concept is borrowed from architecture with current meanings related with changes in an area and/or property, giving a different status to the place, without erasing the previous diverse uses of the site. In plain words, while the idea of renovation brings some aesthetical understandings upon the space, requalificar corresponds to the political, social, and economic interests related to the whole process (Bezerra and Chaves 2014). This research understands that the better word to characterize the work on Romani culture, history, identity, and so forth would be requalificar, and the closest translation to English of this concept would be the word relabel.

14 This statement does not intend to diminish the violence, persecution, and assimilation that Gypsies/Roma faced during the planned economy experiences. Instead, I understand as basic needs access to absolute minimum living conditions, for instance, work. Even these very basic living standards deteriorated after the fall of the so-called socialist regimes. 
sponsors. About the way in which these donors acted upon their arrival in Bulgaria from 1989 onwards, $B$ (2016) says that their approach was "[...] up to bottom, ${ }^{[15]}$ absolutely."

Such an approach is stressed not only by Bulgarian Roma activists but also by interviewees in Hungary and North Macedonia. The latter deserves further comment, because the interviewee affirmed relative freedom in their work, despite the capital coming from donors. However, when asked about the methodology used to work with the community in which their organization was inserted, they confirmed that it was a standard template that originated from donors' headquarters. This is interesting given the fact that $B$ stated several times that the problem with the Western donors' approach was exactly their insistence on imposing methodologies which supposedly worked in different contexts around the world but which were never tested in projects related to Gypsy/Romani populations.

It is fair to assume that Western donors in Central and Eastern Europe bolstered discursive practices about Gypsy/Romani populations as one single ethnic-national group, as the donors originally arrived aiming to deal with the Roma issue and saw Gypsies/Roma as a single and clear-cut national grouping, in a similar way as national minorites were perceived in Western Europe. As observed on OSF's website: “The Open Society Foundations have spearheaded an unprecedented effort, working with Roma communities to secure Roma's rightful position in European society" (The Roma and Open Society 2013, author italics). Yet, for instance, the 1999 OSF annual report points out its support to a "Roma newspaper and magazine" in Bulgaria and awards to "Romani students" in the Czech Republic, among other references (Open Society Foundations Annual Report 1999, 27, 30, author italics).

When engaging with the umbrella term to represent plural Gypsy/Romani populations, OSF is enforcing sets of representations on these plural populations in a universal description of Gypsies/Roma which, in turn, supports the Roma nation ideal. In other words, a Roma nation is not seen here as a cohesive nationalist movement in the traditional frame but as a set of representations which support Gypsies/Roma as a Romani national group. Such representations are instrumentalized and reorganized daily by any international organization that addresses the so-called Roma issue. These representations have their roots in the late nineteenth century, became stronger after the internationalization of Romani organizations in the 1960s, and reached the First World Romani Congress by 1971. These nationalist representations are separated into two main topics and pointed out by Liebich (2007) as "native" and "dative." While the first stressed the common origin of all Gypsies/Roma in today's India, the latter stresses the social-political conditions of those seen or self-ascribed as Gypsies/Roma. Both "ethnic and social identity are not utterly incompatible" (Liebich 2007, 544) and feed one another depending on context, time, and space (Sambati 2019). Furthermore, these representations were the start point from which Western donors embarked in former (so-called) socialist countries.

Such practices find a parallel with Gellner's (1983) theory in which nationalist discourse must be broad: a nationalist narrative is supposed to make sense to a large group and, to this end, it stresses the widespread features which encompass the said large group, while trying to relax the differences - a pattern reiterated

15 Given the context of the interview, it is secure to affirm that by using the expression "top to bottom" the interviewer intended to use the expression top-down, i.e., that the Western donors' approach was coming from headquarters and should be replicated locally as planned. 
by nationalist movements since the mid-nineteenthth century. International Romani organizations in the 1970s, and even in the twenty-first century, have followed a similar path:

As expressed in the International Romani Union's (IRU) Declaration of a Nation, the basis of Roma nationalism is the claim that all 'Roma' constitute a single and distinct political community which requires its own, separate political representation. [...]

This imagined community shares no common language (only a small minority speak one of the dozens of often mutually unintelligible dialects of Romani), culture, religion, identity, history or even ethnicity. Even within countries, Roma minorities are diffuse and diverse and do not function as any kind of actual community (Kovats 2003, 4).

Once landed at full speed in Central and Eastern Europe, Western donors reproduced the slow but uninterrupted understanding of Gypsy/Romani populations as one group, looking for similarities in the group and setting aside particularities - both within the Gypsies/Romani populations themselves and among different minorities with whom these Western organizations might have dealt before and Gypsies/ Roma (Sambati 2019). B (2016) illustrates the case:

For example, the Dutch donors [...] I forgot the name [ $B$ mentions a particular meeting with an important person from a specific Dutch donor]... we had a few discussions with him. And he was very harsh imposing... "It works in Holland...." It was a huge discussion. And I told him, "Look, maybe it works in Holland, with the Moroccan immigrants, but first of all we are not Moroccan. We are Gypsies. Second, we are not immigrants, we have lived here for seven centuries.

The remarks illustrate the frame of mind of this Dutch organization when it came to Bulgaria. They were dealing with the named Roma issue in a national scheme, national here understood as a category of analysis, usually pragmatically enforced without much reflection. When Western donors came to the new "market" to take on the so-called Roma issue, they simply framed their approach to Gypsies/ Roma with the same conceptual and lexical frameworks that they were used to. Wimmer and Schiller (2003) discuss the concept of methodological nationalism defining it as the "[...] naturalization of the nation-state by the social sciences" (Wimmer and Schiller 2003, 576). The authors divide methodological nationalism into three variants: (1) disregard of the relevance of nationalism in modern societies; (2) taking for granted the boundaries between states; and (3) confining the interpretation of a phenomenon to the borders of a country. In this article the discussion on methodological nationalism will be inspired by the ideal presented in the first variant. Specifically, Wimmer and Schiller argue that:

Ignoring is the dominant modus of methodological nationalism in grand theory; naturalization of "normal" empirical social science; territorial limitation of the study of nationalism and state building.

In the first variant of methodological nationalism, ignoring the power of nationalism and the prevalence of the nation-state model as the universal form of political organization are neither problematized nor made objects of study in their own right $(2003,578)$. 
It is necessary to keep in mind that Wimmer and Schiller discuss the academic world; however, skipping over the strength of the nation/nation-state concept when building a worldview is not academia's alone. Western donors have repeated this pattern, applying the same mind-set about national groups belonging to former socialist countries as well as Gypsy/Romani populations. Therefore, donors have separated populations that do not belong to majoritarian groups, setting them aside as part of a nation within a nation, an approach reflected in the actions which they believe(d) to be necessary in order to solve "problems."

This approach appears to fit intellectually with the thinking of well-educated Gypsies/Roma who lived within the borders of so-called socialist countries. That is because a nationalist understanding of the world was also present - even at the expense of denying Gypsy/Romani nationhood. The outcome of this overlap is the formation of a single activist and/or intellectualized elite who enforce a monopoly and apply it to the plural populations known as Gypsies and/or Romani national patterns, even if it sometimes has to gloss over evidence to the contrary. In other words, methodological nationalism might have been supported by sponsors, academia, and activists due to unquestioning allegiance to the concept of nation, mostly because it seems a perfect fit for the context, given the overall acceptance to work on groupings through the lens of an ethno-national arrangement.

In a moment of self-critical introspectiont $B$ explains (2016) : "As I told you, we accepted them as professors in democracy. 'They know how it is... they're the professors, we're the students.' Many of us did!" The process created an environment of shared, similar understanding, where one reinforces the other during the work process as shown in Figure 1.

Figure 1.

Western Donors in Romani Nationalism

\begin{tabular}{|c|c|}
\hline $\begin{array}{l}\text { Western donors } \\
\text { Nationalist understanding } \\
\text { of social grouping }\end{array}$ & Ideological and financial sponsorship \\
\hline $\begin{array}{l}\text { Reports } \\
\text { Results interpreted within the } \\
\text { nationalist understanding of } \\
\text { social grouping }\end{array}$ & $\begin{array}{l}\text { Local Central and } \\
\text { Eastern European Intelligentsia } \\
\text { Formally educated within the nationalist } \\
\text { understanding of social grouping }\end{array}$ \\
\hline $\begin{array}{l}\text { Growing of Activists/ } \\
\text { Intelligentsia }\end{array}$ & $\begin{array}{l}\text { Pragmatic local addressing } \\
\text { of Roma/Gypsy issues } \\
\text { Lack of reflection on the nationalist } \\
\text { understanding of social grouping }\end{array}$ \\
\hline
\end{tabular}


In plain language, local NGOs behave in a certain way not (only) because they ultimately want finances from sponsors but also because they were taught by their sponsors, and therefore their strategies and beliefs are similar. Thus, the connection among local NGOs, activists and sponsors is not only monetary. Such an interpretation can lead to a misunderstanding that local NGOs and activists behave in the way which the sponsors want - and here it is possible to highlight George Soros as the main actor - solely in order to profit financially. Expertise also exerts an influence on pragmatic local action, and together with expertise also came representations in which the characterization of groupings of people in an ethnonational fashion was (and still is) usually organically framed. In order to debate this connection in depth, the next section will analyze closely the case of one of many donors: OSF.

\section{Open Society Foundations within This Process}

Among Western donors, it is hardly disputable how OSF and George Soros stand in the spotlight, not only because of OSF's unwavering financial support toward Gypsies/Roma in Central and Eastern Europe but also because it is one of the few donors that continues to this day to invest in Romani communities since the 1990s. One of the largest geographic actions connected with OSF was the Decade of the Roma Inclusion (2005-2015). According to Brüggemann and Friedman (2017, 2):

The formal decision to establish the Decade was taken at the 2003 conference "Roma in an Expanding Europe: Challenges for the Future," which was held in Budapest. The conference was initiated by the World Bank, co-chaired by World Bank president James Wolfensohn and George Soros, the founder of the Open Society Foundations (OSF). A central motive for the Decade was the perceived need to coordinate sporadic efforts toward the integration of Roma on the part of a great diversity of international and national actors. The 2003 conference was attended by over 500 participants, including nine government leaders and many highlevel government officials, as well as [political] representatives of international organizations, Roma activists and members of NGOs.

Therefore, the Decade of Roma Inclusion was an attempt to engage a coordinated international set of measures aiming to improve the social, economic, and political situation of Gypsies/Roma in countries that once had planned economies as well as in Spain. Nevertheless, Brüggemann and Friedman discussed how, in 2015, at the end of the project, there was an overall understanding that the Decade's programs had failed to change the lives of Gypsy/Romani communities.

$B$ (2016) has the following understanding of the Decade:

Many people don't know what the Decade of the Roma Inclusion is about. [...] It was not understood clearly by the governments, because George Soros brought [...] not the European Union as a partner but the World Bank, and the World Bank means money. And Soros means money, generally. Of course, the governments expected somehow that these two financial institutions would pay them to integrate the Gypsies.... Of course, it didn't happen. Because Soros told them, "Look, you pay for this, I give you only the 
expertise. I have good expertise here, good projects. I will give you prepared people, I'll give you expertise...."

From this excerpt it is possible to imagine the landscape of influence of Western donors bringing methodology of work and expertise - along with their own set of representations to deal with the so-called Roma issue. Moreover, it is necessary to highlight a different arm closely connected to OSF and linked to the process of representing Gypsies/Roma as one nation, the Central European University (CEU).

Soon after the fall of the Iron Curtain a group of people - intellectuals and wealthy businessmen - decided that it would be beneficial to have an academic environment to assist the transition from totalitarian regimes to (allegedly) democratic systems. George Soros was among those people, and from this effort, in 1991, the CEU was born (History 2018). Stewart (2017) attested that the CEU has been working for almost two decades, offering two postgraduate courses with Romani issues in the center of discussion. Furthermore, CEU also runs a summer school with a course dedicated to Romani studies. From 1998 till 2010 were nine annual summer courses, with over 300 participants (CEU Summer University (SUN) 2011).

The existence of the CEU raises the question whether an institution itself can serve as a source of nationbuilding representations of the Gypsy/Romani population. Stewart (2017) points out that intellectuals and scholars connected with CEU recently have begun to relabel the field of Romani Studies, renaming themselves as a Critical Romani Studies. The movement aims to overcome, among other things, the lack of Gypsy/Romani people in high levels of the academic sphere:

So, today, the situation we confront is that an older generation of Romani Studies researchers have provoked a wave of reaction among activist Romani intellectuals that demand 'Roma studies' taught by Roma, that suggests research agendas should be controlled by 'the Roma' or whoever claims to [politically] represent them, and $\mathrm{PhD}$ projects in which there is always one Romani supervisor. 'Nothing about us, without us!', we hear with increasing urgency. 'Who speaks for whom?', the activist-intellectuals demand to know (Stewart 2017, 127).

Stewart's discussion brings into focus a question of exactly who is $u s$ ? It might be said that the us in this equation are each and every Gypsy/Roma around the world. Such an approach is an outcome and a feeder of the nationalist mind-set previously discussed. It is a methodological approach to understand the plural Gypsy/Romani populations within the framework and set of concepts attached to nationalism. In other words, even if while discussing Gypsy/Romani plurality, the very fact of having postgraduate courses, conferences, and summer courses dedicated to Roma issue serves to enforce a discursive elaboration of representations over a Roma nation.

Through its ideological, strategic, and financial sponsorship, Western donors created a possibility for both activism and academic research work with Gypsy/Romani populations via their efforts to deal with the Roma issue. Financial support from the West was channeled to a Gypsy/Romani elite (either intellectual, political, or economic) and then expected to reach the communities. In this sense, the arrival of Western support symbolically legitimated local Romani and Romani-friendly organizations to work with Gypsy/Romani populations and then enabled them to speak on behalf of these communities when 
in dialogue with donors - the entire process underlining the ideal of Gypsy/Roma as one Roma nation. Activists and intellectuals, therefore, evolved as a distinct group which, with their historically constructed privileges, managed to keep themselves at the forefront of Romani social mobilization. Imposing a Roma nation on plural Gypsy/Romani populations appears to be a valid strategy, essentializing specific traits in order to create cohesive mobilization. But it may also have led to unintended consequences like a growing distance between activists and intellectuals and their populations. In short, Roma may have been represented and encircled by a select group of activists and intellectuals without taking fully into consideration how Gypsy/Romani communities might understand themselves.

\section{Essentialist and Nationalist Approaches As Strategy}

At this point it is pertinent to issue a disclaimer: there is no intent here to affirm that the relationship between activists and/or intellectuals and NGOs with Western donors delegitimizes their work. This paper does not believe that this relationship per se can be a problem, although - as will be discussed below - it deserves in-depth analysis. As mentioned earlier, Gellner (1983) debates how nationalist rhetoric must be detailed enough to be connected with a given population, while also simultaneously broad enough in order to reach a large number of people. In doing so, usually some (claimed) features believed to be intrinsic to the population which forms the nation are highlighted; meanwhile, the differences do not gain as much space. Plus, these stressed characteristics are framed in a way in which they seem to congenitally belong to this population, being therefore a set of traits to differenciate this specific grouping from other groupings. This strategy usually leads to a process of essentialization. According to Eide $(2010,66)$ :

Essentialism presupposes that a group or a category of objects/people share some defining features exclusive to the members of this particular group or category. This has been a highly contested idea throughout the social sciences and particularly in post-colonial as well as colonial discourse studies. Essentialism is often discussed together with the questioning of categories like race and nation. On the other hand, at a more pragmatic level, essentialist practices and modes of representation have been applied by groups and individuals in the promotion of certain minority rights or demands (as well as liberation struggles) [...]. Sometimes this is a conscious albeit partial appropriation of an essentialism imposed by others (the elite, the powerful) on the part of a group wanting to achieve certain goals. The group thus tries to define itself by its own criteria, but at times essentialist hegemonic representation is internalised [...]. Essentializing the self may be part of a negotiated halfway adaptation to the rules of the game set by, for example, mainstream media [...].

As Eide affirms, the process of essentialization - here understood as assigning certain characteristics to one particular category of people perceived as one single group - is the usual strategy of unrelated types of organizations, especially when paired with an elaboration of nationalist rhetoric. In Eide's ideal, the process of essentialization is either an external set of actions that have a tendency to other the essentialized group or a strategic set of discursive practices that are developed in order to strengthen the fight for the rights of a minority (both options do not necessarily exclude one another). In this sense, it might be said that the strategy of essentializing some (claimed) historical-cultural traits toward Gypsy/Romani 
populations through Roma nation representations serves a purpose: to elevate the quality of life of those among these populations who have suffered any kind of economic, political, and social disadvantage, and/or antigypsyist everyday violence - either physical or psychological. Romani activists are not the first to employ such practices. The strategy to essentialize a claimed group can be seen as an attempt to standardize a public image of the collective, despite the internal plurality of the group: "[...] thus advancing their group identity in a simplified, collectivized way to achieve certain objectives" (Eide 2010, 76). Ryazanov and Christenfeld (2018), for instance, see processes of social essentialism in a positive way and bring cases which illustrate the complexity of process of essentialization and de-essentialization:

Increasingly, evidence suggested that essentialism may be a flexible conversational resource, rather than a cognitive style. [...] In a sample of Dutch majority and minority participants, Verkuyten (2003) found that both ethnic minority and majority participants used essentialism flexibly when discussing multicultural issues. Dutch (majority) participants essentialized culture when discussing how different cultures coexisting is inherently problematic but used de-essentialist arguments when discussing minority groups needing to assimilate into their culture. Conversely, minority group participants essentialized culture and claimed a right to their identity when resisting assimilationism. When challenging the majority view that their group is negative and homogenous, they adopted a de-essentialist position. Such research provides initial evidence that essentialism is flexibly used to advance competing goals - essentialism can decrease responsibility for a group's position but can be rejected to avoid being entirely defined by group membership. Because these goals appear to be traded off, rejecting the meaningfulness of group membership may come at the cost of increased responsibility for group (or individual) status (Ryazanov and Christenfeld 2018, 3-4).

If the strategy in itself seems to be justifiable, it might be interesting to raise the question: is essentialization a collective decision (collective understood to be the majority of individuals belonging to the claimed group) or is it a discursive practice developed by (claimed) members of the group who (claim to) speak on behalf of all? That is relevant to ask because, when Ryazanov and Christenfeld describe social essentialism as a viable social strategy, they are considering in-group essentialism; they are debating experiences when small groups talk among and about themselves and interchange between essentialization and deessentialization in debates in which they are included. Therefore, it seems relevant to question whether the strategy to essentialize particular (claimed) features upon Gypsy/Romani populations is organized on a communitarian level or developed by activists and/or intellectuals from their specific perspective. The distance between Romani and Romani-friendly organizations and communities, already emphasized in this article, points to the latter. Thus, such strategies and practices can be seen as vanguardism.

When discussing strategies in which the working class could organize themselves and fight for the improvement of the quality of their working and living conditions, Chomsky (2004) uses the notion of avant-garde parties. Keeping in mind the differences between the two realities - labor unions/parties and Romani and Romani-friendly organizations - it is possible to draw here a parallel. Chomsky calls avantgarde parties those who aim to take the control of the labor class from a central committee, with promises to work on their behalf and for their benefit. Political parties might apply such a strategy to any group that claims, at any kind of level, to represent politically and/or to fight in the name of a broad population with 
some goal - whether clear or otherwise. Thus, in an ideal scenario for avant-garde groups, they would be formed by elites (which can be economic, intellectual, or prestigious) within a given group. These elites have the character of being an outcome of former privileges, as well as profiting from and developing different privileges once invested within their role as representatives.

It is not being affirmed here that any organization that has a connection to Western donors and that happens to be reinforcing the use of the nation to work with Gypsy/Romani populations is operating on behalf of their own privileges, in a highly Manichean way. Nevertheless, it seems that those activists and intellectualized groups who managed to have access to training and money from Western donors already enjoyed some level of privileges historically constructed within the societies in which they lived. ${ }^{[16]}$ Therefore, this position of speaking on behalf of Gypsies/Roma is sensitive, because from Chomsky's (2004) perspective, when one puts oneself in the position of representing a group, there runs a risk of the representative eventually detaching from the group which they claim to represent, no longer observing and interpreting the (claimed) represented as fully an insider but from a privileged perspective. The essentialization of (claimed) characteristics upon Gypsies/Roma as a nation is perceived by part of the Romani intelligentsia and activists as a way to call attention to their problems, exorcize a past full of brutality, and provide a chance to envision a brighter future.

Roma characterized as a nation might be one way to fight against prejudice and exclusion, but it might also be a prolific space for the sprouting of vanguard groups, who are usually disconnected from those who might be in need, and may well lead to a vicious circle of social handouts which generally do not achieve any measurable impacts among communities. According to Liebich (2007), narratives which tend to enforce Romani identity can be both the basis for exoticizing and othering the Gypsies/Roma or the legitimization of the Romani struggle, together with the empowerment of Romani activists, but are unlikely to help to address the Roma problem in Central and Eastern Europe. Liebich's understanding from 2007 seems to materialize in 2015, with the end of The Decade of Roma Inclusion - sponsored mostly by Western organizations like the ones discussed in this article - which did not emphatically decrease the social, political, and economic distance between Gypsy/Romani and non-Gypsy/non-Romani populations in Central and Eastern Europe (Kovats and Surdu 2015; Brüggemann and Friedman 2017). Kovats and Surdu $(2015,13)$ go further:

Placing all Roma into an anti-discrimination paradigm as a way of fostering their inclusion seems not to be an effective method for solving individual cases of abuse and mistreatment but has led to largely cosmetic changes to particular exclusionary mechanisms. Though repeatedly identified as a high priority, institutional anti-discrimination initiatives have been too limited to create a critical mass, producing only symbolic victories that leave unchanged the root causes of unequal treatment.

16 This affirmation cannot be misinterpreted as saying that these people did not suffer any level of antigypsyism or other type of violence. Rather, that among those seen or self-ascribed as Gypsy/Roma, they were those who had the formal skills to enter dialogue with the new group. 


\section{Final Considerations}

The end of so-called socialism in Central and Eastern Europe allowed easier mobility within the European continent, not only for intellectuals and activists from the East to the West but also for finances traveling the other way. A new paradigm was installed, and Western donors became increasingly influential and affected the landscape of Romani and Romani-friendly organizations. It was no longer a question of a circumscribed group of intellectuals and activists thinking about (sometimes ungrounded) international strategies to boost the idea of Roma as a nation but local organizations that could be instrumentalized in their everyday work within Romani communities by the representations created by their predecessors. That may be attributed to Western donors that arrived in Central and Eastern Europe aiming to work on the Roma issue and to local organizations that embraced this approach, and learnt and adapted the Western point of view. The angle through which Western donors understood the Gypsy/Romani population in Eastern Europe, in turn, had a strong influence on the nationalist approach developed since the 1970s. Such a cyclical interaction trickled down into the mind-set of Eastern organizations. In their local work, NGOs ended up forging and re-forging nationalist feeling in an endless exercise of continuous mutation. Since the 1960s an international effort has sought to use the umbrella concept of Roma to gather all the different populations that were known, considered, or self-ascribed as Gypsies in Europe. This same mind-set was applied by Western donors: they also saw these plural populations as the Roma and, with their financial support, they taught people to act locally (Gypsies/Roma and nonGypsies/non-Roma) within these same parameters. Therefore, the generalized representations of Roma grew in stature and impact, at least among activists, academia, and intelligentsia - whether Gypsy/Roma or non-Gypsy/non-Roma.

The agenda to characterize Gypsy/Romani populations as one Roma nation can be interpreted as a strategic essentialization or, in other words, as a set of actions aiming to empower Romani and Romanifriendly organizations through discursive practices that can bring different organizations together, highlighting (allegedly) similar targets. Such procedures are usually part of the nation-building process throughout history, and strategic essentialism has been used by different minorities in their struggle for life improvement. Nevertheless, it seems relevant to bring up the question of who are the people deciding which traits are acceptable to be essentialized and which ones are not. It is fair to say that activist and/or intellectualized groups, even though carrying a history of engagement, scholarship, and self-reflection, are a socially privileged grouping within their context and, furthermore, can - willingly or otherwise - reinforce such a position. Gradually, they could grow alienated from Gypsy/Romani everyday life, resulting in interpretations, representations, and essentializations from a perspective that no longer understands Gypsy/Romani challenges in-depth. Thus, there comes a great responsibility with such a position, and no one should be devoid of potential (self) criticism. 


\section{References}

B. 2016. "The Situation of the Romani People and the Romani Social Movements in Bulgaria." Interview by Douglas Neander Sambati. Personal archive.

Barany, Zoltan. 2000. "Politics and the Roma in State-Socialist Eastern Europe." Communist and Post-Communist Studies 33 (4): 421-37. https://doi.org/10.1016/S0967-067X(00)00014-3

Bezerra, Aline Maria Marques, and César Roberto Castro Chaves. 2014. "Revitalização Urbana: Entendendo o Processo de Requalificação Da Paisagem.” Revista Do CEDS 1: 1-16.

Brüggemann, Christian, and Eben Friedman. 2017. “The Decade of Roma Inclusion: Origins, Actors, and Legacies.” European Education 49 (1): 1-9. https://doi.org/10.1080/10564934.2017.1290422

Carmona, Sarah. 2013. "Memory, History and Romanipen: Reflection on the Concept of Trace." In Roma Identity and Antigypsyism in Europe, edited by Christo Kjučukov and Omar Rawashdeh. Munich: LINCOM Europa.

Central European University. n.d. "History." Budapest: Central European University. https://www.ceu.edu/about/ history.

—. 2011. "CEU Summer University (SUN). CEU Celebrates Its 20th Anniversary: 1991-2011." 24 March 2011. http://20.ceu.edu/blogs/guest/2011-03-24/ceu-summer-university-sun

Chartier, Roger. 1990. A História Cultural: Entre Práticas e Representações. Rio de Janeiro: Bertrand.

Chomsky, Noam. 2004. “Reforma e Revolução.” In Notas Sobre o Anarquismo, 161-86. São Paulo: Imaginário.

Eide, Elisabeth. 2010. "Strategic Essentialism and Ethnification." NORDICOM Review 31 (2): 63-78. https://doi. org/10.1515/nor-2017-0130

Gellner, Ernest. 1983. Nations and Nationalism. First edition. New Perspectives on the Past. New York: Cornell University Press.

Hancock, Ian. 2001. "Foreword." In Between Past and Future: The Roma of Central and Eastern Europe, by Will Guy, VII-IX. Hertfordshire: University of Hertfordshire Press.

- 2005. We Are the Romani People / Ame Sam e Rromane Džene. Interface Collection. Hertfordshire: University of Hertfordshire Press.

Kovats, Martin, and Ian Law. 2018. Rethinking Roma: Identities, Politicisation and New Agendas. Mapping Global Racisms. London: Palgrave Macmillan.

Kovats, Martin. 2003. “The Politics of Roma Identity: Between Nationalism and Destitution.” OpenDemocracy, July 29, 2003, sec. Home. https://www.opendemocracy.net/en/article_1399jsp/.

Liber, George. 1991. "Korenizatsiia: Restructuring Soviet Nationality Policy in the 1920s." Ethnic \& Racial Studies 14 (1): 15.

Liebich, Andre. 2007. "Roma Nation? Competing Narratives of Nationhood." Nationalism and Ethnic Politics 13 (4): 539-54. https://doi.org/10.1080/13537110701678270

M. 2016. "The Situation of the Romani People and the Romani Social Movements in North Macedonia." Interview by Douglas Neander Sambati. Personal archive.

Martin, Terry. 2001. The Affirmative Action Empire: Nations and Nationalism in the Soviet Union, 1923-1939.

London: Cornell University Press. 
Marushiakova, Elena, and Vesselin Popov. 2004. “The Roma - a Nation Without a State? Historical Background and Contemporary Tendencies." In Segmentation Und Komplementarität. Organisatorische, Ökonomische Und Kulturelle Aspekte Der Interaktion von Nomaden Und Sesshaften, edited by Bernhard Streck, 71-100. Halle.

_ 2008. “Soviet Union before World War II." In Information Fact Sheets on Roma History. Strasbourg: Council of Europe.

- 2013. "Roma Identities in Central, South-Eastern and Eastern Europe." In Roma Identity and Antigypsyism in Europe. edited by Christo Kjučukov and Omar Rawashdeh. Munich: LINCOM Europa.

Mayall, David. 2004. Gypsy Identities, 1500-2000: From Egipcyans and Moon-Men to the Ethnic Romany. London: Routledge.

McGarry, Aidan. 2008. "Ethnic Group Identity and the Roma Social Movement: Transnational Organizing Structures of Representation." Nationalities Papers, 2008.

Niremberg, Jud. 2009. "Romani Political Mobilization from the First International Romani Union Congress to the European Roma, Sinti and Travellers Forum." In Romani Politics in Contemporary Europe: Poverty, Ethnic Mobilization, and the Neoliberal Order, edited by Nando Sigona and Nidhi Trehan, 94-114. New York: Palgrave Macmillan.

Open Society Foundations. 1999. “Open Society Foundations Annual Report 1999.” Budapest: Open Society Foundations. https://www.opensocietyfoundations.org/sites/default/files/a_a_complete_99_0.pdf.

—. 2013. “The Roma and Open Society." Budapest: Open Society Foundations. May 2013. https://www. opensocietyfoundations.org/explainers/roma-and-open-society.

Rövid, Márton. 2011. “One-Size-Fits-All Roma? On the Normative Dilemmas of the Emerging European Roma Policy." Romani Studies 21 (1): 1-22.

Ryazanov, Arseny A., and Nicholas J. S. Christenfeld. 2018. “The Strategic Value of Essentialism.” Social \& Personality Psychology Compass 12 (1): 1-1. https://doi.org/10.1111/spc3.12370

Sambati, Douglas Neander. 2019. 'Historical Sociology of the Romani Nationalism: Foundations, Developent, and Challenges'. PhD thesis, Prague: Charles University.

Simhandl, Katrin. 2009. "Beyond Bounderies? Comparing the Construction of the Political Categories 'Gypsies; and 'Roma' Before and After the EU Enlargement." In Romani Politics in Contemporary Europe: Poverty, Ethnic Mobilization, and the Neoliberal Order, edited by Nando Sigona and Nidhi Trehan, 72-93. New York: Palgrave Macmillan.

Stalin, Iosif Vissariónovitch. 2012. Marxism and the National Question. London: CPGB-ML.

Stewart, Michael. 2017. "Nothing about Us without Us, or the Dangers of a Closed-Society Research Paradigm." Romani Studies 27 (2): 125-46. https://doi.org/10.3828/rs.2017.8

Surdu, Mihai, and Martin Kovats. 2015. “Roma Identity as an Expert-Political Construction.” Social Inclusion 3 (5): 5-18. https://doi.org/10.17645/si.v3i5.245

Vermeersch, Peter. 2006. The Romani Movement: Minority Politics and Ethnic Mobilization in Contemporary Central Europe. Studies in Ethnopolitics. New York: Berghahn Books.

Wimmer, Andreas, and Nina Glick Schiller. 2003. "Methodological Nationalism, the Social Sciences, and the Study of Migration: An Essay in Historical Epistemology." The International Migration Review 37 (3): 576-610. 